NBER WORKING PAPER SERIES

\title{
DO RICH AND POOR COUNTRIES SPECIALIZE IN A DIFFERENT MIX OF GOODS? EVIDENCE FROM PRODUCT-LEVEL US TRADE DATA
}

\author{
Peter K. Schott \\ Working Paper 8492 \\ http://www.nber.org/papers/w8492 \\ NATIONAL BUREAU OF ECONOMIC RESEARCH \\ 1050 Massachusetts Avenue \\ Cambridge, MA 02138 \\ September 2001
}

Special thanks to Richard Baldwin. Thanks as well to Andrew Bernard, Peter Kenen and seminar participants at Columbia University, the $7^{\text {th }}$ Annual EIIT Conference, the University of Florida, the London School of Economics, the University of Oregon, the NBER Summer Institute, Princeton University and the Yale School of Management. Written comments from two anonymous referees and the NBER ITI group were very helpful. The views expressed herein are those of the author(s) and not necessarily those of the National Bureau of Economic Research.

(C) 2001 by Peter K. Schott. All rights reserved. Short sections of text, not to exceed two paragraphs, may be quoted without explicit permission provided that full credit, including (C) notice, is given to the source. 
Do Rich and Poor Countries Specialize in a Different Mix of Goods?

Evidence from Product-Level US Trade Data

Peter K. Schott

NBER Working Paper No. 8492

September 2001

JEL No. F11, F14, F2, C21

\begin{abstract}
Unit values of US imports at the product level reveal a substantial degree of vertical product differentiation among countries exporting to the US. This specialization is not apparent by looking solely at trade flows. Two trends stand out. First, the portion of US import products originating in either rich or poor countries exclusively has fallen dramatically as US trade barriers have fallen, from $41 \%$ in 1972 to $17 \%$ in 1994 . Indeed, by 1994 , nearly three quarters the products imported into the US were sourced simultaneously from rich and poor countries. Second, within-product unit value dispersion is positively and significantly correlated with source country income: men's shirts imported from Japan in 1994, for example, are about thirty times as expensive as shirts originating in the Philippines. These unit value premia, and their increase over time, are consistent with the factor proportions framework but convey a stark warning: industry trade flow data alone are too coarse to meet the assumptions underlying most tests of trade theory.
\end{abstract}

Peter K. Schott

Yale School of Management

135 Prospect Street

New Haven, CT 06520-8200

and NBER

Tel: 203-436-4260

Fax: 203-432-6947

Email: peter.schott@yale.edu

homepage: http:/www.som.yale.edu/faculty/pks4/ 


\section{Do Rich and Poor Countries Specialize in a Different Mix of Goods? Evidence from Product-Level US Trade Data}

\section{Issues}

Do rich and poor countries compete by producing and trading the same mix of goods? Both Heckscher-Ohlin and product cycle models of trade imply low levels of direct competition between rich and poor countries because each has a cost advantage in producing a different mix of goods. Labor abundant countries should produce labor intensive products, for example, and capital abundant countries should produce capital intensive products. Nevertheless, empirically assessing the relevance of endowment-motivated trade is hampered by the coarse division of output contained in most international trade data. When products are assigned to just a few dozen industries, most countries are observed to import and export all of them, hampering our ability to differentiate vertical trade in different products from horizontal trade in different varieties. In this paper we use product-level unit values to distinguish between these two types of intra-industry trade.

Controlling for vertical differentiation is important for interpreting existing tests of standard trade theory. The factor proportions framework traditionally is estimated by drawing upon trade flow, endowment and input intensity data to determine whether the factors embodied in a country's trade are equal to its relative factor abundance. ${ }^{1}$ Most recent contributions to this literature assume - implicitly or explicitly - that countries produce the same mix of goods and that they manufacture them using identical techniques. ${ }^{2}$ Support for the model is generally weak in these tests, and the field has turned toward generalizing them to allow for international productivity differences and home bias (e.g. Davis and Weinstein 1998; Trefler 1995). However, the greater the vertical product differentiation between rich and poor countries, the more unreliable these tests are. Indeed, the degree of differentiation reported here is a strong

\footnotetext{
${ }^{1}$ See, for example, Bowen et al (1987), Leamer (1984), Harrigan $(1995,1997)$ and Trefler $(1993,1995)$.

${ }^{2}$ Davis and Weinstein (1998) allow input intensities to vary with country capital abundance and report strong evidence for endowment-motivated trade. Schott (2001) takes a different tack in finding strong support for the factor proportions framework; he shows that countries do appear to enter and exit industries in a manner consistent with theory when industries are redefined according to input intensity rather than end use. This adjustment is a means of teasing product level information out of industry-level data.
} 
argument for directing greater suspicion at specialization in resolving what has become known as the "mystery of the missing trade" (Trefler 1995).

We attack this problem head-on by exploiting highly detailed US trade flow data that segment trade into thousands of products and record product-level unit value by origin country. We examine a much broader set of countries -120 of the poorest and richest versus the 30 or so OECD countries typically studied - because vertical Heckscher-Ohlin specialization is more apt to appear between more dissimilar countries.

Two trends stand out. First, if we rank US trade partners by per capita GDP, we find that the number of products imported from rich or poor countries exclusively has declined sharply with time: in 1972, 41\% of import products originated only in rich countries and 1\% originated only in poor countries; by 1994 , these shares had fallen by half, to $17 \%$ and $0.4 \%$, respectively. Second, and more striking, we find that unit values rise with origin country income. Men's shirts from Japan, for example, are about thirty times as expensive as shirts originating in the Philippines. By comparison, the Economist reports that the global price variation of the McDonald's Big Mac, a highly standardized good, was 3.3 using existing exchange rates in March 1999. In our sample of goods going to the same market, the median high to low unit value ratio across all products in 1994 is 24, and this ratio increased over time.

By itself, the rising product mix overlap between rich and poor countries is surprising and appears to contradict the factor proportions framework. Observation of unit values, however, resolves this puzzle by showing that, within product classifications, labor abundant poor countries are shipping the US different goods than capital and skill abundant rich countries. Indeed, these unit value premia increase over time, a trend highly suggestive of rich countries' efforts to reduce direct competition with poor countries as trade barriers fall. Together, these trends contain a stark warning: industry trade flow data alone are too coarse to differentiate vertical from horizontal trade specialization and therefore do not meet the assumptions underlying most tests of trade theory.

Using unit values to discern trade specialization is a recent addition to a long line of research aimed more broadly at measuring intra-industry trade. This research begins with Grubel and Lloyd (1975), who develop a widely used index for measuring bilateral, within-industry trade flows. Subsequent work by Greenaway and Milner (1983) highlights the insensitivity of this index to vertical versus horizontal intra-industry trade. Our approach is most similar to 
Greenaway, Hine and Milner (1995), who use per-ton industry unit values to measure the relative importance of vertical and horizontal trade in Canadian imports. A significant advantage of this paper is the use of unit values by product and classification (e.g. dollars per dozen shirts) rather than industry and weight. Also, we emphasize the importance of endowments in explaining vertical trade rather than the role of market structure and scale economies in spurring horizontal trade. Nevertheless, the high but relatively equal unit values we find among rich countries is consistent with the horizontal specialization implied by "new" trade theory (e.g. Krugman 1979, 1981; Lancaster 1980; Stiglitz 1987). Indeed, use of product-level unit values would seem to be a useful addition to empirical investigation of those models (e.g. Hummels and Levinsohn 1993, 1995).

Understanding the extent of vertical product specialization, along with market structure and scale, is a key part of identifying who wins and loses as a result of international trade. ${ }^{3}$ From 1972 to 1994, the portion of US manufacturing value imported from the poorest countries increased fourfold, from $2 \%$ to $8 \%$. But the share of trade "touched" by poor countries is much larger: by 1994, manufacturing import products with at least one poor country as a source represented nearly three quarters of the total value of manufacturing imports. The effect of this poor country competition on firms in rich countries is under-explored and deserves more attention. $^{4}$ In the Heckscher-Ohlin framework, for example, rich country firms producing a good in common with Chinese firms have two options if economic integration lowers the good's world price. The first is to match the price decline and continue direct competition by either lowering wages or increasing productivity (possibly by outsourcing). The second is to exit the market either outright or by introducing a related but higher end product that takes advantage of their countries' greater skill and capital abundance. To the extent that firms exit or upgrade, the link

\footnotetext{
${ }^{3}$ Greenaway, Hine and Milner (1995) and Gibson and Harris (1996) offer detailed discussions of the theory of how these relate to welfare gains from trade.

${ }^{4}$ Caves (1998) and Sutton (1997) provide summaries of research in firm turnover and growth. To the extent that this work does take on an international focus, it is typically with the purpose of understanding the effect of trade liberalization on firms in developing countries (Tybout 2000, 2001). Two exceptions to this trend are Feenstra and Hanson (1996) and Bernard and Jensen (2001). The former study outsourcing by US firms; the latter show that US plant closures occur more frequently in regions that are experiencing rapidly changing relative factor supplies and in industries with factor requirements at odds with the new supplies.
} 
between the low-end good's world price and rich country factor rewards is weakened, an affect which may mitigate political opposition to trade. In this paper we find that rich countries have widened the distance between their products and those of poor countries over time.

Finally, we note that an important limitation of our analysis is that it is not a true "test" of the factor content of trade in the sense advocated by Bowen et al (1987). On the other hand, such a test is not possible here because input intensities are not available at the product level. In addition, because empirically distinguishing measures of relative endowments and technological prowess is quite difficult, we cannot determine the extent to which Ricardian technological differences (e.g. Dornbush, Fisher and Samuelson 1977) play a role in the vertical specialization we uncover. Nevertheless, these limitations are offset by the significant compensating advantage of being able to peer into products for the first time.

The paper proceeds as follows: section 2 briefly outlines the theory behind trade specialization and highlights its empirical implications; section 3 provides a brief description of the product-level US import data used in the empirical analysis; section 4 reports the evidence; and section 5 concludes with suggestions for future research.

\section{Specialization and Trade}

In the multiple cone equilibrium of Heckscher-Ohlin (HO) trade theory, a country's product mix varies according to its relative factor endowments. The top panel of Figure 1 displays a two factor, four product world. The four products, in order of increasing capital intensity, are Apparel, Textiles, Machinery and Chemicals. Under standard assumptions (see Dixit and Norman 1980), the four products' unit-value isoquants delineate three cones of diversification, the word cone referring to the set of endowment vectors that all select the same mix of products. Because production of a good outside of the cone in which a country resides results in negative profit, GDP-maximizing countries produce only the two goods anchoring their cones. As drawn, Japan and the Philippines each have a distinct product mix, with capital abundant Japan specializing in relatively capital intense Machinery and Chemicals and labor abundant Philippines specializing in relatively labor intense Apparel and Textiles. ${ }^{5}$

\footnotetext{
${ }^{5}$ In this example, countries in neighboring cones produce one good in common. More generally, with $F$ factors, two countries in neighboring cones can produce from zero to $F-1$ such common goods. See Bernard, Jenson and Schott
} 
If, as indicated by the arrow in the figure, a country accumulates capital relative to labor, its product output per total labor force evolves as indicated in the bottom panel of Figure 1. First, in the labor abundant (or poor country) cone, capital accumulation reduces Apparel output while raising Textile output. Second, in the middle cone, capital accumulation reduces Textile output at the expense of Machinery output. Finally, in the capital abundant (or rich country) cone, capital accumulation reduces Machinery output at the expense of Chemical output.

Capital accumulation also moves a country into cones with progressively higher wages and lower capital rental rates. This change in relative factor rewards can be seen by connecting isoquants with their respective isocost lines. Unit value isoquants are tangent to their respective isocost lines as a result of perfect competition. In Figure 1, a decline in the price of Textiles lowers nominal wages in the labor abundant cone but does not affect nominal wages in the most capital abundant cone. Thus, factor price equality is maintained within cones but can vary across countries in different cones. This feature of the model highlights the importance of measuring vertical product specialization. If Japan is sufficiently more capital abundant than the Philippines to produce a non-overlapping mix of goods, the competition between workers in the two countries is weakened. All else equal, a decline in the world price of Apparel raises real wages in Japan.

The development paths in Figure 1 highlight the similarity between HO and technologydriven product cycle (PC) specialization. To the extent that product capital intensity is correlated with technological sophistication, and country capital abundance is correlated with innovative prowess, both predict similar product entrance and exit patterns. In product cycle theory, Leader output rises until Followers figure out how to manufacture and enter the market, whereupon Leader output declines. Leaders have the advantage because their large, rich markets provide firms with a strong incentive to invent sophisticated products (Posner 1961, Vernon 1966, 1979). A “quality ladder" variant of this model has Leader and Follower trading dominance of a particular good over time, as Leaders re-enter the market for a given good by innovating and offering a more advanced version (Grossman and Helpman 1991). Without clearer measures of

(2001) and Leamer (1987) for more detailed discussions of output specialization when standard HO assumptions, including evenness, are relaxed. 
industry sophistication and its correlation with endowments, empirically differentiating $\mathrm{HO}$ and PC development paths is quite difficult. ${ }^{6}$

Countries rarely exhibit product mix specialization at the industry level. At the level of aggregation used in most empirical trade research (i.e. the three digit International Standard Industrial Classification that breaks manufacturing into 28 industries), countries produce and trade all industries. The difficulties associated with this coarseness can be observed in Figure 1 by renaming the four products T-shirts, Televisions, Gore-Tex Jackets and Flat Panel Displays in order of capital intensity. If these products are grouped into two industries, Apparel and Electronics, then Japan and the Philippines have positive production of both industries. In that case, the two countries experience intra-industry trade and only unit value data permit us to distinguish vertical from horizontal specialization. This data would show a correlation of unit value with source country capital abundance. If we add an additional capital abundant economy and allow for both red and blue Gore-Tex Jacket production, the identical unit values of these two Apparel products would be evidence of the type of horizontal differentiation implied by new trade theory (e.g. Helpman and Krugman 1984).

We search for two trends in support of endowment-driven trade. The first is that products imported from the poorest countries are different from products originating in the richest countries. The second is that when poor countries invade import product markets previously held by rich countries, rich countries upgrade their product mix to reduce direct competition. Examination of unit values is key to uncovering both trends.

\section{Data Description and Summary}

The NBER Trade Database (NBERTD) compiled by Feenstra (1996) lists the customs value of all US imports by source country for the years 1972 through $1994 .^{7}$ Imports are

\footnotetext{
${ }^{6}$ Feenstra and Rose (2000) find that the order in which countries first export goods to the US is consistent with macroeconomic rankings typically associated with technological prowess. However, that study relies upon industry rather than product data and does not examine whether Leaders exit once Followers enter, which we do not find. Indeed, the export persistence we report below is consistent with Gagnon and Rose's (1995) finding that disaggregated national trade balances switch sign very slowly.
} 
classified according to the seven digit Tariff Schedule of the United States (TS) from 1972 through 1988 and according to the ten digit Harmonized System (HS) from 1989 through 1994. The switch from TS, an exclusively US system, to HS, a multilateral system governed by the World Customs Organization, was motivated by an effort to increase international standardization of reporting trade statistics. For the remainder of this proposal, we refer to seven digit TS (TS7) and ten digit HS (HS10) imports as "goods" or "products". Imports at higher levels of aggregation, such as the one digit Standard International Trade Classification (SITC1), are referred to as "industries". Table 1 lists examples of HS10 products, by SITC1 industry. In the empirical work to follow, we omit products belonging to the ninth SITC1 industry, Not Elsewhere Classified.

The NBERTD also provides quantity and unit information for a large number of goods, rendering possible the calculation of unit values. ${ }^{8}$ Availability of unit value information ranges from $77 \%$ of country-good observations in 1972 to $82 \%$ in 1994 , with unit values for natural resources generally being more available than for manufactures. Machinery, arguably the most heterogeneous industry, has the lowest coverage, growing from $56 \%$ of country-good pairs in 1972 to roughly $70 \%$ in 1994 . This growth is largely attributable to an increase in electronics trade.

Examples of the units employed include dozens of shirts in apparel, square meters of carpet in textiles and pounds of folic acid in chemicals. Our use of US import data to discern vertical product differentiation assumes implicitly that what other countries export to the US reflects their productive potential. This assumption is partially justified by the relative openness of the US economy and its attractiveness as an export destination. Nevertheless, the existence of tariff and non-tariff barriers may cause some countries to produce a broader range of goods than

\footnotetext{
${ }^{7}$ As noted in the documentation accompanying the NBERTD, customs value is the value upon which duties are assessed. It does not include shipping charges and is intended to serve as an arm's-length transaction value for the commodity.

${ }^{8}$ NBERTD unit values are not without error. In a 1995 study, the General Accounting Office identified underlying product variation (studied more broadly here) and classification error as the two major sources of unit value dispersion in an in-depth analysis of eight products. Classification error included inaccurate recording of units and misclassification of goods. Value-weighted unit values are used in cases where multiple product-country observations exist in a single year.
} 
they send to the US. To the extent that rich countries produce but do not export goods that are exported by poor countries, and vice versa, this limitation can lead us to overstate the level of international specialization. Data which might be used to measure this problem are not available. Some solace can be taken from the likelihood that production but not export of a good signals a lack of international competitiveness.

The total number of products imported into the US ranges from roughly 8,000 in 1972 to approximately 16,000 in 1994 . The left panel of Figure 2 provides a breakdown of the number of products by SITC1 industry and shows that the principal effect of switching from TS7 to HS10 in 1989 was to reduce the number of Manufactured Materials goods at the expense of Machinery, Chemical and Food goods. ${ }^{9}$ This drop, and the large number of apparel and textile goods, in Miscellaneous Manufactures and Manufactured Materials, respectively, may have a political economy element: it may have been easier for the US to restrict trade from poor countries prior to 1988 under the unilateral TS than under the subsequent multilateral HS.

The bottom panel of Figure 2 plots import value by industry. Machinery accounts for the largest share of value and rose substantially in the mid 1980s with the surge in US auto imports. The figure also illustrates the sharp volatility of Fuel imports, a factor which may affect unit values and is discussed again in Section 4.2. The relative value of Miscellaneous Manufactures rises steadily starting in the early 1980s, spurred by a more-than-doubling of the value of apparel imports from 1982 to 1994. Overall, from 1972 through 1994, real imports grew at an average annual rate of approximately $7 \%$ per year.

Finally, Figure 3 illustrates the extent to which aggregation can obscure specialization by making it appear as if all countries export all goods to the US. At the SITC1 industry level, 75\% of country-industry observations have positive exports to the US in 1994. At the TS/HS product level, however, just $10 \%$ of country-product observations are non-zero in the same year. This discrepancy is even starker in manufacturing, where all countries export all SITC1 manufacturing industries to the US in all years.

\footnotetext{
${ }^{9}$ A breakdown of SITC2 industries (not shown) reveals that Textiles (SITC2 65) and Apparel (SITC2 84) consistently have the largest number of goods under both systems, accounting for 30\% and $15 \%$ of all goods under TS, respectively. Each accounts for roughly $11 \%$ of goods under HS. By comparison, the next largest SITC2 industry, Organic Chemicals (SITC2 51), contains roughly 5\% of total goods under both systems.
} 


\section{Measuring Specialization via Origin Country Endowment Cohorts}

Because specialization is more apt to appear the more dissimilar the countries examined, it is important to seek the largest possible sample of countries. Here, we use per capita GDP (PCGDP) from the 2000 World Bank CD-ROM rather than capital per worker to identify capital abundance because the former is available for roughly twice the number of countries (i.e. 120 versus 60 ). In any case, the correlation between the two series, for countries for which both are available, is on the order of $90 \%$.

\subsection{US Import Products Increasingly Originate from a Diverse Set of Countries}

We rank countries as "poor", "middle" and "rich" according to their position in the world income distribution using the $30^{\text {th }}$ and $70^{\text {th }}$ PCGDP percentiles as cutoffs. Countries are poor if they are in the $0-30^{\text {th }}$ percentile range; middle if they are in the $30^{\text {th }}-70^{\text {th }}$ percentile range, and rich if they are in the $70^{\text {th }}-100^{\text {th }}$ percentile range. Countries are re-ranked each year to control for movement along the types of development paths outlined in section 1.2. Under this system, in 1994 Japan is a rich country, the Philippines is a middle country and Nicaragua is a poor country. Several countries - including three from Asia - transition permanently out of "poor" and into "middle" between 1972 and 1994. We list them in Table 2 along with their year of transition. They are discussed further below.

Using country ranks, we group products into to six origin country cohorts depending upon the mix of countries that export the product to the US. If a product is in the Poor, Middle or Rich cohorts, it originates solely in poor, solely in middle or solely in rich countries, respectively. These groups are meant to correspond to capture the type of HO specialization outlined above: highly labor intense products, for example, should originate solely in poor countries. Products are in the Poor \& Middle (P\&M) or Middle \& Rich (M\&R) cohorts, on the other hand, if they are sourced simultaneously from at least one country of each type. These two cohorts are constructed as a partial robustness check on our income cutoffs and are meant to capture goods that come from mostly poor and mostly rich countries, respectively. Finally, if a product is in the Poor, Middle \& Rich (PM\&R) cohort, it originates in at least one country of all three income types. Origin cohorts are mutually exclusive.

The evolution of import products and value by origin cohort is striking. Figure 4 reveals that in 1972, 41\% of import products and 19\% of import value originated solely in rich countries. 
By 1994, these shares had fallen substantially. During the same period, the share of products originating in countries of all three income types (i.e. PM\&R products) rises steadily, from $48 \%$ in 1972 to $74 \%$ in $1994 .{ }^{10}$ A similar trend occurs with respect to value. Even more dramatic shifts (not shown) occur at the SITC1 industry level: while 70\% of Chemical products originate in rich countries in the 1970 s, for example, less than $30 \%$ do so by 1994 . Alone, these results imply that intra-industry trade is growing substantially between the very set of countries - rich versus poor - where it is least expected according to endowment-driven trade models.

We also find that products do not tend to cycle between rich and poor countries over time. Origin-cohort transition probabilities (not reported) indicate that the share of PM\&R goods remaining PM\&R goods increases with time and is roughly $90 \%$ in 1994 . Conversely, Rich products have an increasing tendency to become PM\&R products and a declining tendency to remain Rich products over time. These trends violate the product cycle implications of endowment- and technology-driven trade.

Rapidly developing economies provide a partial explanation for why poor countries are invading markets previously dominated by rich countries. Between 1972 and 1994 the portion of PM\&R products imported from just one poor country increases from $20 \%$ to $35 \%$, with most of the rise occurring between 1987 and 1994. One explanation for these single-poor-country $\mathrm{PM} \& \mathrm{R}$ products is that relative endowments in rapidly growing economies render them ready to adopt a rich country product mix before it is reflected in their GDP. It is also possible that firms in rapidly growing economies, rationally anticipating relative endowment growth, begin production of rich country products before it is statically optimal to do so. If these hypotheses are correct, then the transitioning poor countries identified in Table 2 should be influential in defining the single-poor-country PM\&R products.

Figure 5 reports a breakdown of the single-poor-country PM\&R products over time. The transitioning economies (primarily Thailand, the Philippines and Indonesia) comprise roughly $20 \%$ of the single-poor-country PM\&R products until the mid 1980s, after which they are no

\footnotetext{
${ }^{10}$ Results are not sensitive to a $30^{\text {th }}-70^{\text {th }}$ percentile split for classifying countries by income. Qualitatively similar results are obtained when using $10^{\text {th }}-90^{\text {th }}$ and $20^{\text {th }}-80^{\text {th }}$ splits; a major difference is that the portion of trade attributed to poor countries falls off faster. Results are also very similar if we increase the threshold for counting countries' participation in a product to either (1) the $10^{\text {th }}$ or $20^{\text {th }}$ percentile of all goods' import values; or (2) the $10^{\text {th }}$ or $20^{\text {th }}$ percentile of each good's import value.
} 
longer poor. The influence of China and India in defining these goods is stronger, but even though they do not formally jump income cohorts during the sample period, both move from being very poor in 1972 to quite near the $30^{\text {th }}$ percentile in 1994 . The influence of these large countries may also be due to their relatively high intra-national specialization. Coastal provinces in China, for example, increasingly resemble manufacturing-intense Asian tigers, while inland provinces remain heavily concentrated in agriculture.

\subsection{Unit Values Rise with Origin Country Income}

Characterizing trade without information on both price and quantity is inadequate. Figure 6 provides a vivid view of vertical product differentiation via scatter plots of unit value versus source country PCGDP for four products in 1994. In the figure, the size of country labels is scaled according to value.

The first three scatters in the figure - for CRT monitors, men's cotton shirts and dyed woven fabrics - focus on manufactures, while the fourth - fuel oil - is a natural resource commodity. Perhaps unsurprisingly, Fuel oil exhibits no relationship between price and source country income. Each of the manufactured goods, however, exhibits a positive and significant correlation between origin country income and unit value. Indeed, as indicated in the upper right panel, men's shirts from Japan are about thirty times as expensive as shirts originating in the Philippines. By comparison, the Economist reports that the global price variation of the McDonald's Big Mac, a highly standardized good, was 3.3 using existing exchange rates in March 1999. In our sample of goods going to the same market, the median high to low unit value ratio across all products in 1994 was 24.

We characterize the extent of the correlation between unit value and origin country per capita GDP across goods more formally by estimating regression slopes by product and year

$$
\log \left(u_{p i c t}\right)=\alpha_{p i t}+\beta_{p i t} \log \left(p c g d p_{c t}\right)+\varepsilon_{\text {pict }},
$$

where $u_{\text {pict }}$ is country c's unit value of product $p$ in industry $i$ in year $t$ and $p c g d p_{c t}$ is country $c$ 's per capita GDP in year $t$. Table 3 summarizes the significance of $\beta_{p i t}$ across all PM\&R 
goods with at least five country observations. ${ }^{11}$ Each row of the table reports the percent of significant slope coefficients at the $10 \%$ level for each year as well as the number of products with at least five observations in that year. As indicated, the number of products containing vertical product specialization increases over time, from 30\% in 1972 to $43 \%$ in 1994.

To gauge the sensitivity of unit values to per capita GDP within and outside manufacturing, we pool products by SITC1 industry and include fixed effects to estimate a single slope for each industry and year

$$
\log \left(u_{p i c t}\right)=\alpha_{p i t}+\beta_{i t} \log \left(p c g d p_{c t}\right)+\varepsilon_{p i c t}
$$

Results are reported in Table 4. Each column of the table contains the slopes for a different industry; each row for a different year. Coefficients are in boldfaced type if they are significant at the $1 \%$ level. The correlation between unit value and per capita GDP is weak for Beverages, Fuels and Animal Oils, but economically strong and statistically significant in the four manufacturing industries. In Machinery in 1994, for example, a 10\% increase in per capita GDP is associated with a $13 \%$ increase in unit value. In addition, the rising value of slopes suggests an increase in the degree of vertical specialization over time in all manufacturing industries except Machinery, where it is relatively high throughout. The strong link between unit value and origin country income in the Food and Materials industries is somewhat inconsistent with our thinking of them as resource-intense industries, but may be due to the fact that many products in these industries involve a fair amount of capital-intensive processing (e.g. the canning of food or the roasting of coffee).

A more careful measurement of the degree to which vertical specialization increases over time must rely upon a non-varying set of products. Toward that end, we re-estimate equation (2) on the constant set of products classified as PM\&R in 1972. Resulting slopes and 95\% confidence intervals are presented graphically by manufacturing industry and year in Figure 7 . The estimated degree of unit value dispersion does increase with time in Chemicals, Manufactured Materials and Miscellaneous Manufacturing. This increase is a strong signal that rich countries respond to poor country competition via vertical product differentiation.

\footnotetext{
${ }^{11}$ Results do not change substantially with higher observation cutoffs.
} 
Figure 7 highlights an interesting bubble in unit value dispersion in Chemicals, Machinery and Manufactured Material during the 1970s. Comparison of this figure with the breakdown of import value in the bottom panel of Figure 2 suggests that this bubble is influenced by Petroleum prices. To the extent that Chemical and Machinery products are manufactured in a more petroleum-intensive manner in rich countries than in poor countries, the unit values of these products may rise disproportionately during oil price shocks. Then, after the crises pass, the abnormal jump in unit value premia reverses. This hypothesis cannot be verified formally without data on input intensities across countries, and that data is not available at the product level. Nevertheless, it is supported by the fact that the unit value dispersion bubble is most pronounced in Chemicals, which, among the four manufacturing industries, is most likely to be petroleum intense.

Before concluding, we note that alternate interpretations of unit value dispersion merit further exploration. Unit value measurements, for example, may be contaminated by intra-firm transfer pricing. The decline in the share of products originating solely in rich countries, exhibited above, is likely due both to freer consumer trade and to more prevalent global outsourcing (Feenstra and Hanson 1996). To the extent that US-based multinationals source inputs from developing countries with lower labor costs, and seek to minimize tax liability in those locations, actual unit values may vary from the unit values reported on customs documents. Such behavior could increase the likelihood of finding evidence of specialization, but controlling for it is difficult with existing datasets. One check that is possible is to determine whether unit value dispersion is due to intermediate input trade. Following $\mathrm{Ng}$ and Yeats (1999), we classify imports as intermediate inputs if their TS7 or HS10 descriptions contain the word "parts". Regression results are not sensitive to omitting these products but deeper inquiry is likely to be fruitful.

It is also possible that unit values are contaminated by asymmetric US importer leverage. If US importers are able to obtain lower prices from producers in poor countries than producers in rich countries, perhaps due to imperfect information, unit value ratios will be biased upwards. Though it is hard to believe such asymmetry would endure, data for testing this hypothesis should be sought. 


\section{Further Research}

This paper documents two striking trends. First, we show that the number of US imports originating simultaneously in rich, middle and poor countries has increased markedly over time. Second, we find that even though imports are originating in an increasingly diverse set of countries, their unit values are positively and significantly correlated with source country income.

Taken together, these trends support the kind of vertical product specialization implied by the Heckscher-Ohlin model of trade. Unfortunately, data constraints prevent a more complete test of the model at the product level. In particular, the absence of cross-country, product-level input intensity measures prevents us from determining whether the factors embodied in productlevel world trade are equal to countries' relative endowments. We also cannot rule out the possibility that vertical specialization is driven by variation in technology rather than endowments because country income is too general to distinguish between the two. These limitations are mitigated by the ability to measure within-product variation among such a large set of countries for the first time.

The tendency for rich country unit values to be high and poor country unit values to be low is also consistent with the kind of horizontal trade in varieties implied by trade theory incorporating monopolistic competition and scale economies. Both rich and poor countries appear to send the US varieties that are priced similarly to those of other countries in their income cohort. Thus, our results provide support both "old" and "new" trade theory. Further effort to incorporate product-level unit value data into tests of hybrid trade models, therefore, is likely to be fruitful.

Finally, our results indicate that a deeper exploration of vertical product differentiation is necessary to advance our understanding of the affects of globalization on firms and workers. As rich countries seek to differentiate their product mix from that offered by poor countries, direct competition between workers earning vastly different salaries may decline, impacting welfare gains as well as political opposition to trade. Variation in poor country import competition at the product and industry levels likely plays a strong role in how US output, employment and productivity have evolved over the last few decades. In addition, differential exposure to such competition may also shed light on historical and future variation in US regional economic performance. 


\section{Bibliography}

Bernard, Andrew B. and J. Bradford Jensen. 2001. Who Dies? International Trade, Market Structure and Plant Closures. NBER Working Paper 8327.

Bernard, Andrew B., J. Bradford Jensen and Peter K Schott. 2001. Factor Price Equality and the Economies of the United States. NBER Working Paper W8068.

Bowen, Harry P, Edward E. Leamer and Leo Sveikauskas. 1987. Multicountry, Multifactor Tests of the Factor Abundance Theory. American Economic Review 77(5):791-809.

Caves, Richard E. 1998. Industrial Organization and New Findings on the Turnover and Mobility of Firms. Journal of Economic Literature 36:1947-1982.

Davis, Donald R. and David E. Weinstein. 1998. An Account of Global Factor Trade. Mimeo, Harvard University.

Dixit, A. and V. Norman. 1980. Theory of International Trade. New York: Cambridge University Press.

Dornbush, R., Stanley Fisher and Paul Samuelson. 1977. Comparative Advantage, Trade and Payments in a Ricardian Model with a Continuum of Goods. American Economic Review 67:823-839.

Feenstra, Robert C. 1996. U.S. Imports, 1972-1994: Data and Concordances. NBER Working Paper 5515.

Feenstra, Robert C and Gordon Hanson. 1996. Globalization, Outsourcing, and Wage Inequality. NBER Working Paper 5424.

Feenstra, Robert $\mathrm{C}$ and Andrew K. Rose. 2000. Putting Things in Order: Trade Dynamics and Product Cycles. Review of Economics and Statistics (forthcoming).

Gagnon, Joseph E. and Andrew K. Rose. 1995. Dynamic Persistence of Industry Trade Balances: How Pervasive is the Product Cycle? Oxford Economic Papers 47: 229-248.

General Accounting Office. 1995. US Imports: Unit Values Vary Widely for Identically Classified Commodities. Report GAO/GGD-95-90.

Gibson, John K. and Richard I. D. Harris. 1996. Trade Liberalization and Plant Exit in New Zealand Manufacturing. Review of Economics and Statistics 78:521-529.

Greenaway, David and Chris Milner. 1983. On the Measurement of Intra-Industry Trade. Economic Journal 93: 900-908.

Greenaway, David, Robert Hine, Chris Milner. 1995. Economic Journal 105:1505-1518. 
Grossman, Gene M. and Elhanan Helpman. 1991. Innovation and Growth in the Global Economy. Cambridge: MIT Press.

Grubel, H. G. and P. J. Lloyd. 1975. Intra-industry Trade: The Theory and Measurement of International Trade in Differentiated Products. New York: Wiley.

Harrigan, James. 1995. Factor Endowments and the International Location of Production: Econometric Evidence for the OECD, 1970-1985. Journal of International Economics 39:123141.

Harrigan, James. 1997. Technology, Factor Supplies and International Specialization: Estimating the Neoclassical Model. American Economic Review 87(4):475-494.

Helpman, E. and P. Krugman. 1984. Market Structure and Foreign Trade. Cambridge: MIT Press.

Hummels, David, and James Levinsohn. 1995. Monopolistic Competition and International Trade: Reconsidering the Evidence. Quarterly Journal of Economics 110:799-836.

Hummels, David, and James Levinsohn. 1993. Product Differentiation as a Source of Comparative Advantage? American Economic Review 83:445-449.

Krugman, Paul. 1979. Increasing Returns, Monopolistic Competition and International Trade. Journal of International Economics 9:469-479.

Krugman, Paul. 1981. Intraindustry Specialization and the Gains from Trade. Journal of Political Economy 89:959-973.

Lancaster, Kevin. 1980. Increasing Returns to Scale, Monopolistic Competition and International Trade. Journal of International Economics 10:151-75.

Leamer, Edward E. 1987. Paths of Development in the Three-Factor, n-Good General Equilibrium Model. Journal of Political Economy 95:961-999.

Leamer, Edward E. 1984. Sources of International Comparative Advantage. Cambridge: MIT Press.

$\mathrm{Ng}$, Francis and Alexander Yeats. 1999. Production Sharing in East Asia: Who Does What for Whom and Why? World Bank Policy Research Working Paper Series.

Posner, M. V. 1961. International Trade and Technical Change. Oxford Economic Papers 41:323-341.

Schott, Peter K. 1999. One Size Fits All? Specialization, Trade and Income Inequality. NBER Working Paper W8244 
Stiglitz, J. E. 1987. The Causes and Consequences of the Dependence of Quality on Price. Journal of Economic Literature 25:1-48.

Sutton, John. 1997. Gibrat's Legacy. Journal of Economic Literature 35:40-59.

Trefler, Daniel. 1995. The Case of the Missing Trade and Other Mysteries. American Economic Review 85(5):1029-1046.

Trefler, Daniel. 1993. International Factor Price Differences: Leontief was Right! Journal of Political Economy 101:961-987.

Tybout, James R. 2001. Plant- and Firm-Level Evidence on "New" Trade Theories. NBER Working Paper 8418.

Tybout, James R. 2000. Manufacturing Firms in Developing Countries: How Well Do They Do, and Why? Journal of Economic Literature 38:11-44.

Vernon, Raymond. 1979. The Product Cycle Hypothesis in a New International Environment. Oxford Bulletin of Economics and Statistics 41:255-267.

Vernon, Raymond. 1966. International Investment and International Trade in the Product Cycle. Quarterly Journal of Economics. 
Figure 1: Heckscher-Ohlin Specialization and Product Cycles
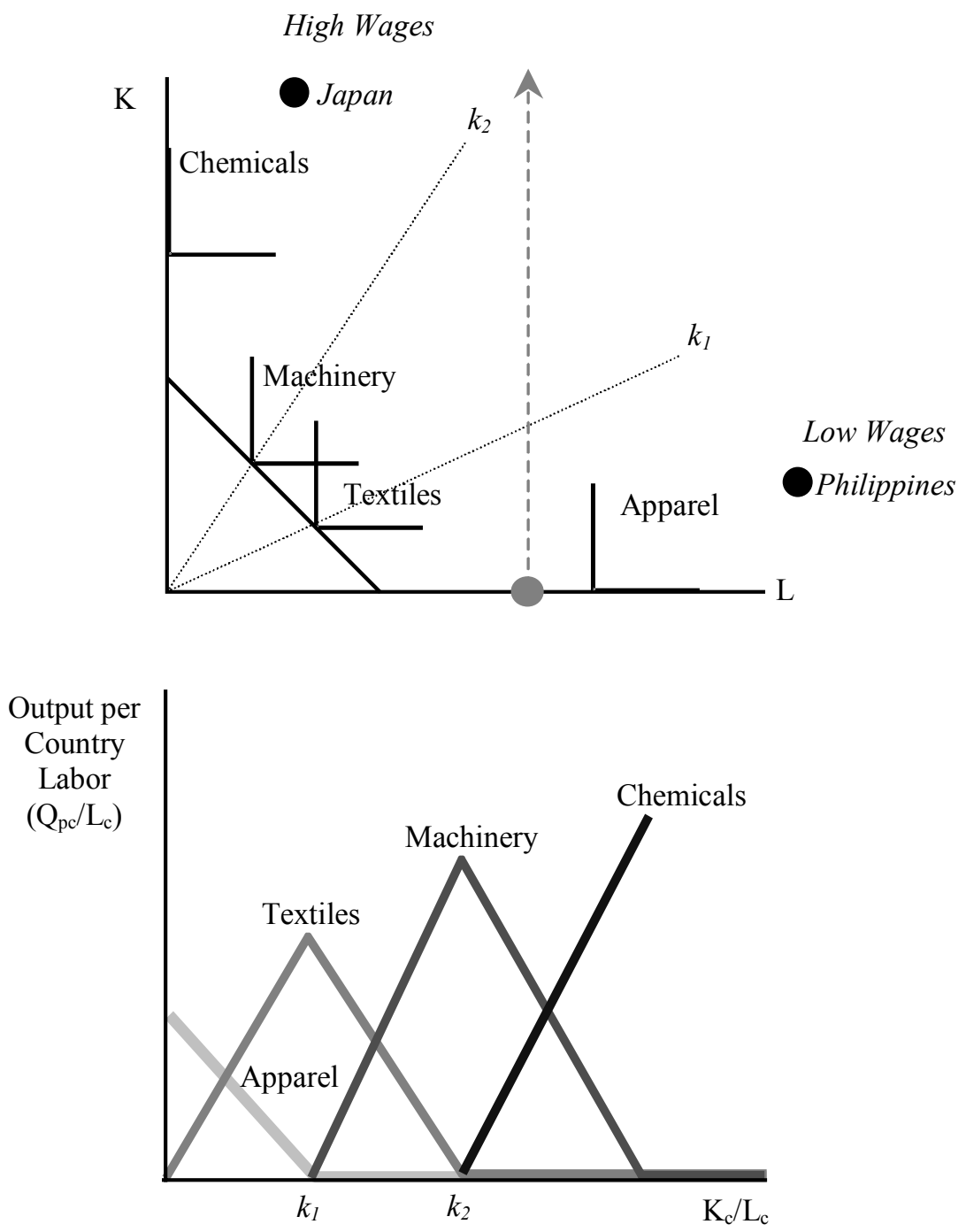
Figure 2: Breakdown of US Import Products and Value by SITC1 Industry

\section{Product Breakdown}

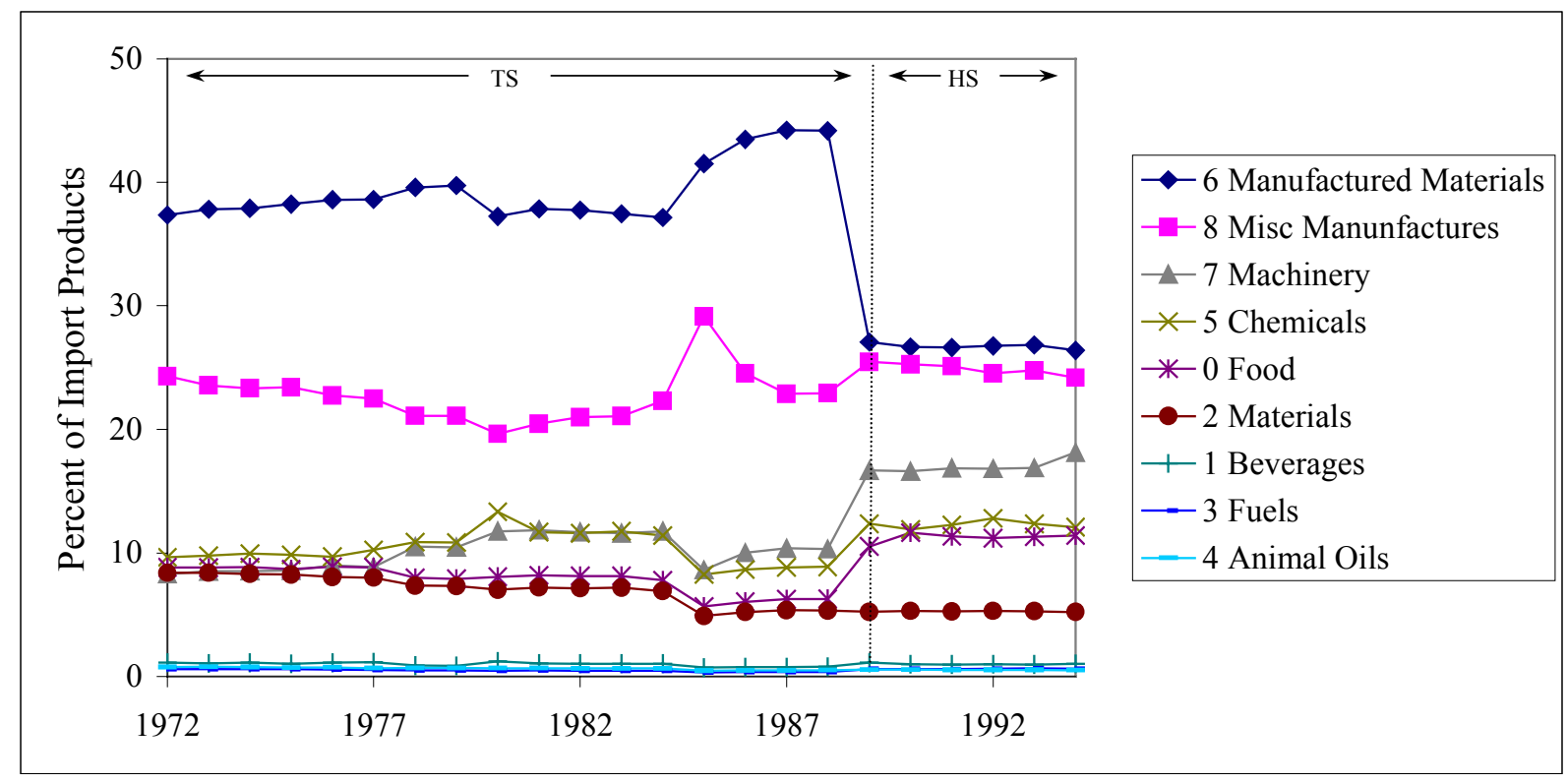

Value Breakdown

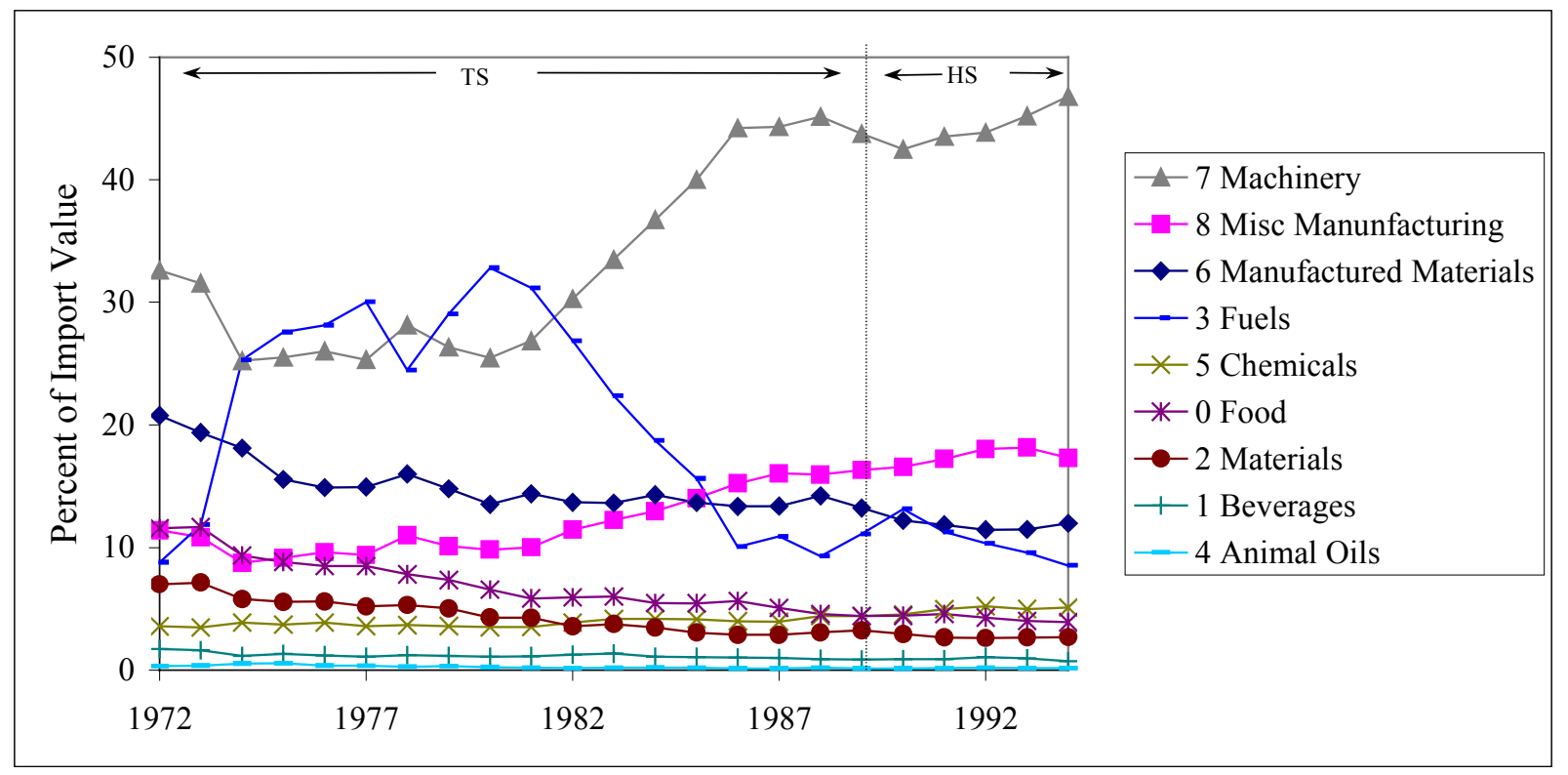


Figure 3: Percent of Non-Zero Country-Industry

Observations By Level of Industry Aggregation

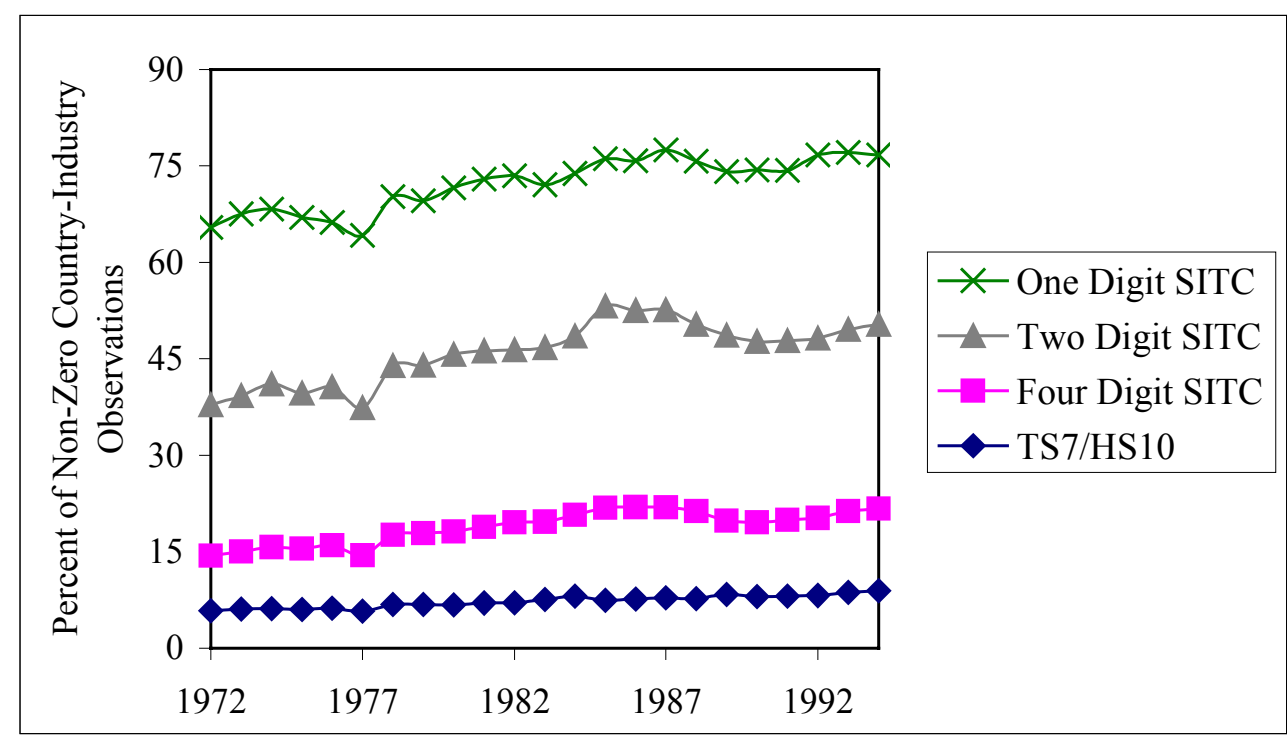

[1] Trends report portion of country-industry cells with zero exports to the US in each Year.

[2] SITC is Standard International Trade Classification. SITC4 industries are more finely defined than SITC1 industries.

[3] TS7 product codes are used from 1972-1988. HS10 product codes are used from 1989-1994. 
Figure 4: US Import Products and Value by Origin Income Cohort

\section{Product Breakdown}

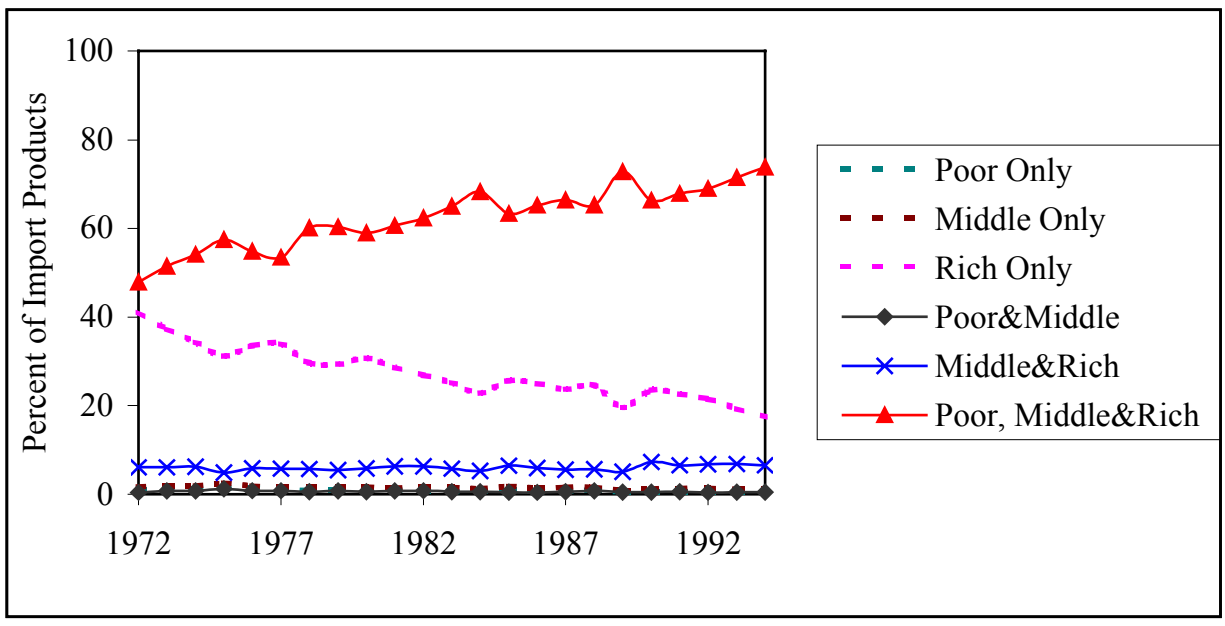

Value Breakdown

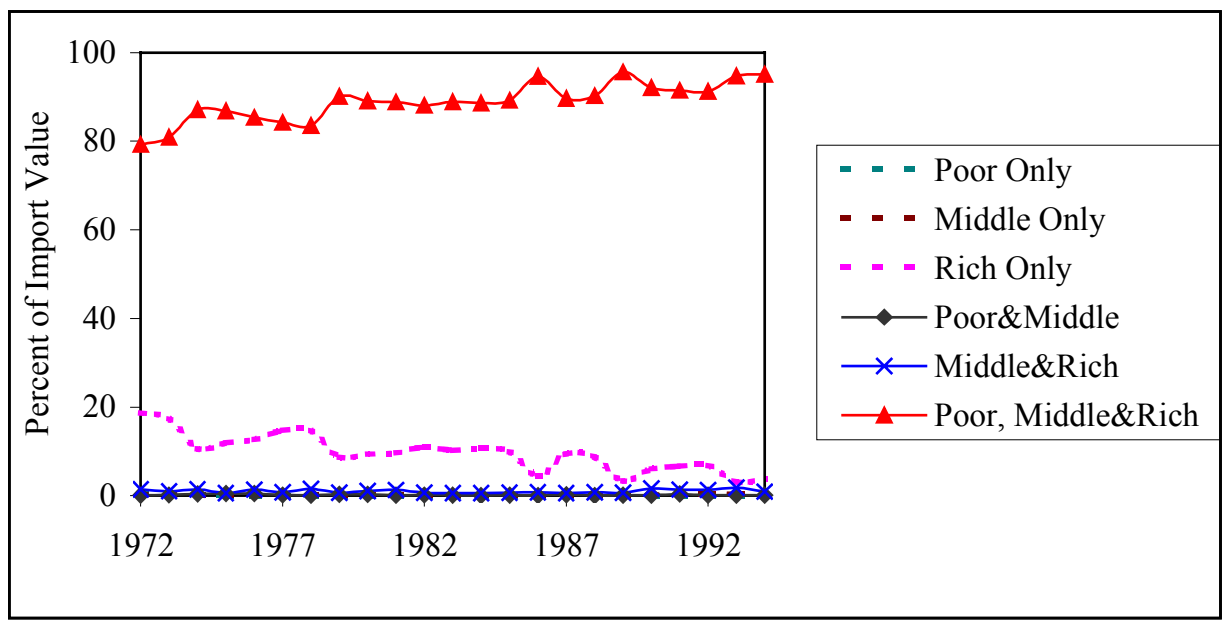

[1] Origin income cohorts classify US import products by the income level of countries in which they originate. "Poor Only" products originate solely in poor countries; PM\&R products, on the other hand, are imported from at least one country of each type. Origin income cohorts are mutually exclusive.

[2] Countries are "poor", "middle" or "rich" if their per capita GDP is in the 0-30, 30-70 or 70-100 percentile range; countries are re-ranked each year. 
Figure 5: Breakdown of Poor, Middle \& Rich (PM\&R) Products

Defined by A Single Poor Country

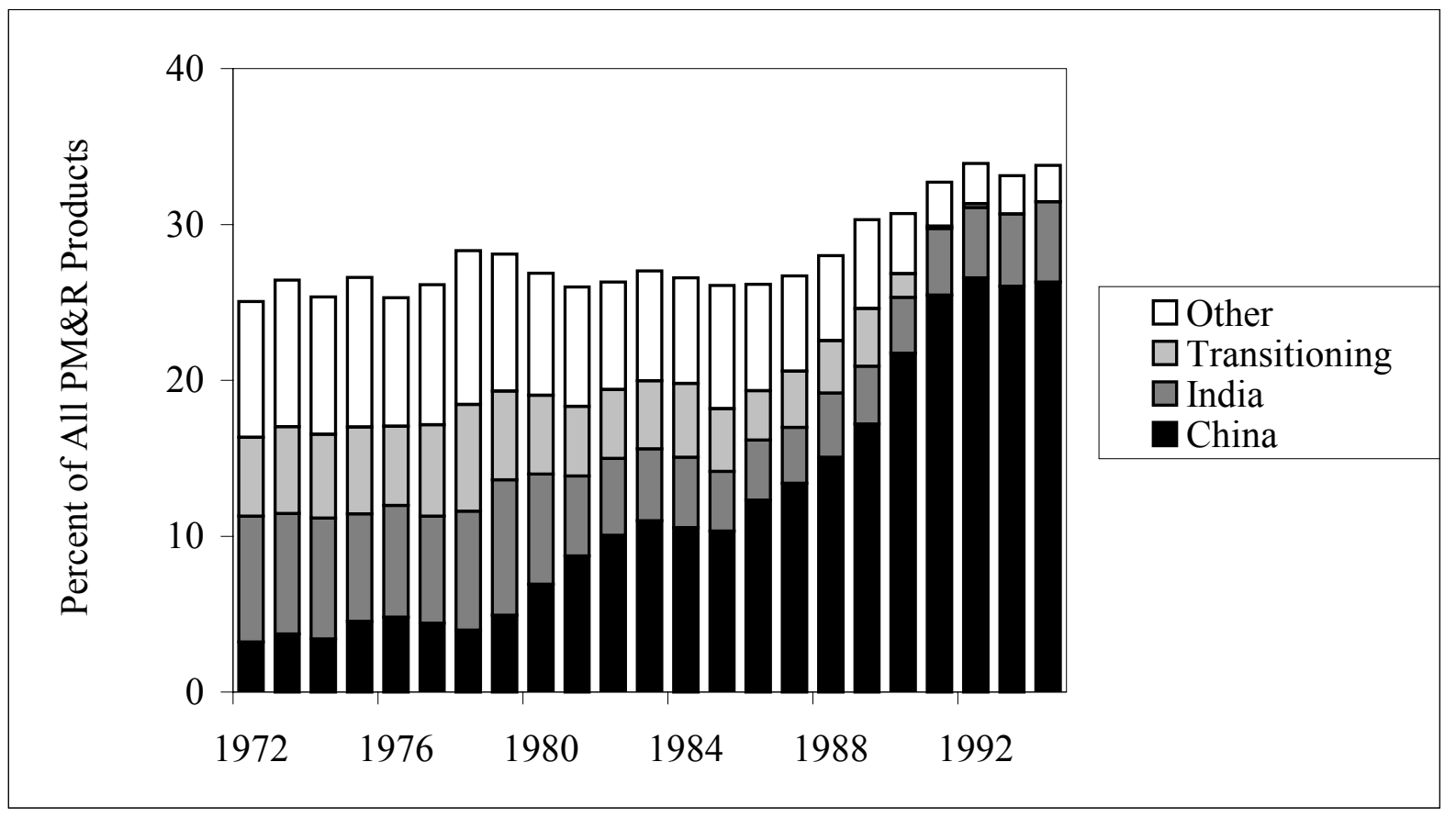

[1] Bars track the portion of $P M \& R$ products defined by a single poor country and identify which poor country it is.

[2] $P M \& R$ products are imported from at least one poor, one middle and one rich country. Countries are "poor", "middle" or "rich" if their per capita GDP is in the 0-30, 30-70 or 70100 percentile range; countries are re-ranked each year. 
Figure 6: 1994 US Import Unit Value vs Origin Country Per Capita GDP for Four Products
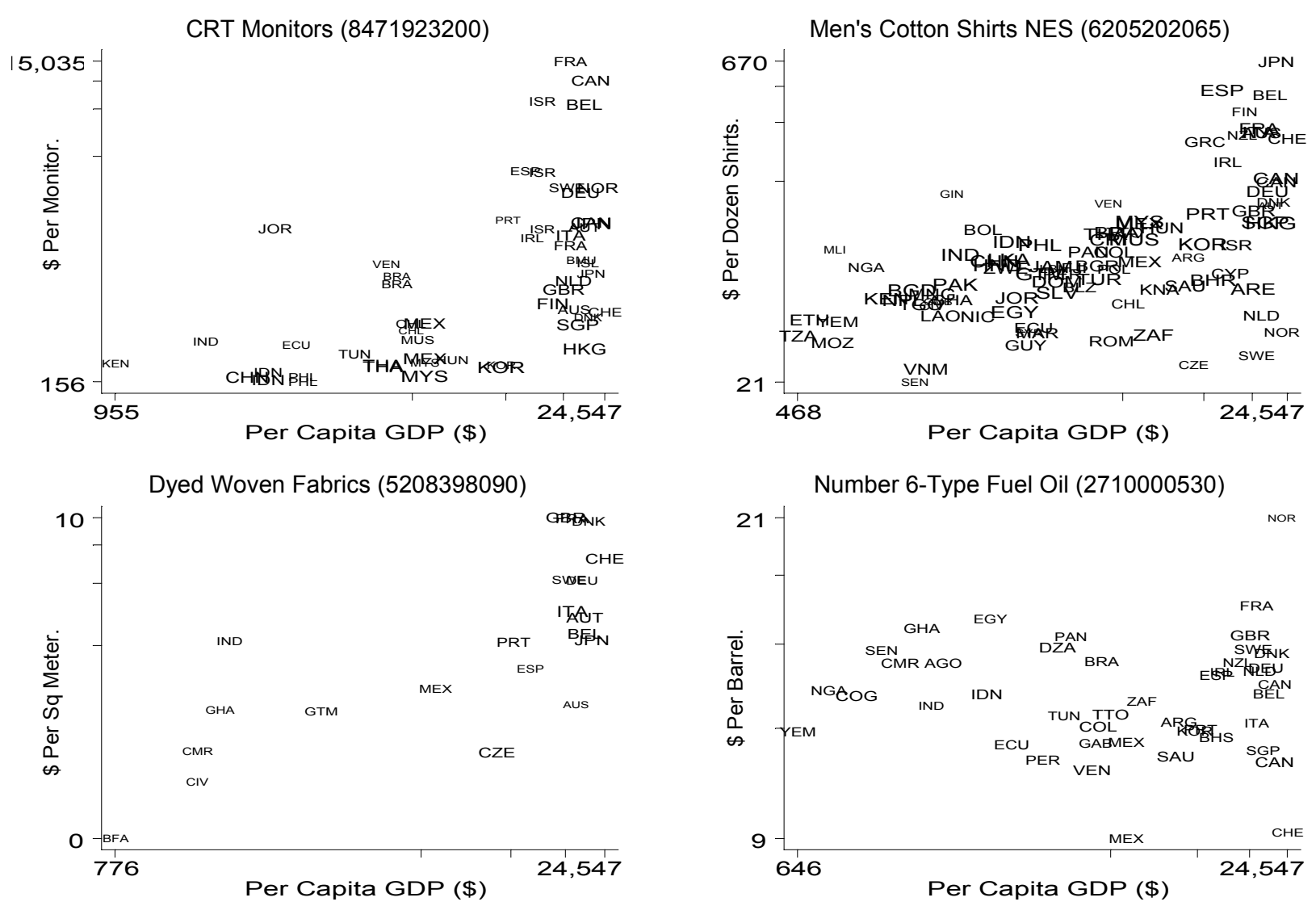

[1] HS10 product code provided in parentheses.

[2] Country labels are proportional to log import value.

[3] Axes are log scaled. 
Figure 7: The Widening Gap Between Rich and Poor Country Products Over Time:

Manufacturing Industry $\beta_{s t}$ 's and 95\% Confidence Intervals

from Equation 2 on 1972 PM\&R Products

Chemicals ( $\mathrm{SITC} 1=5)$

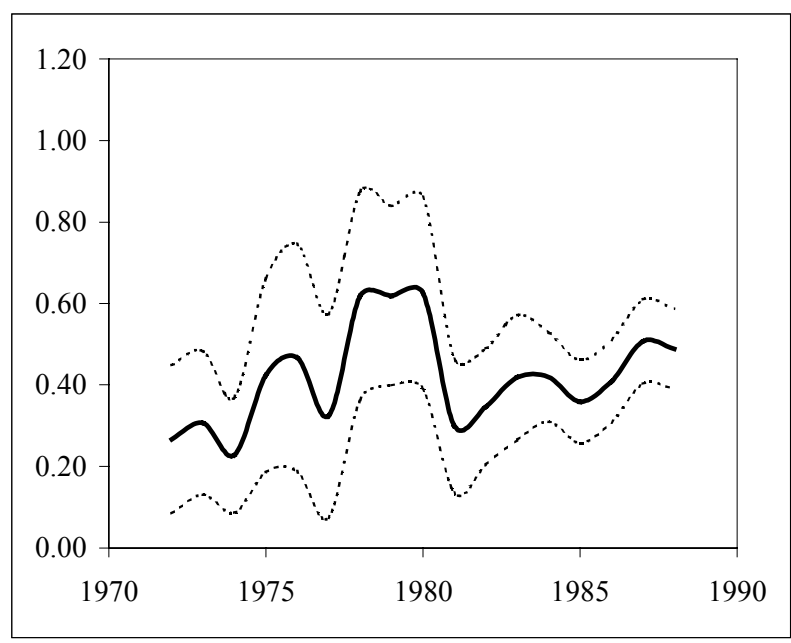

Machinery (SITC1=7)

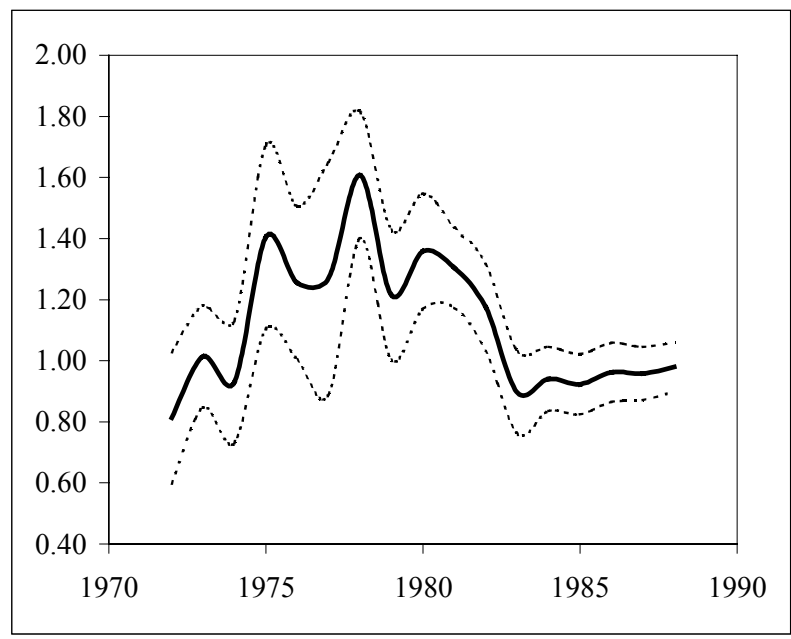

Manufactured Materials (SITC1=6)

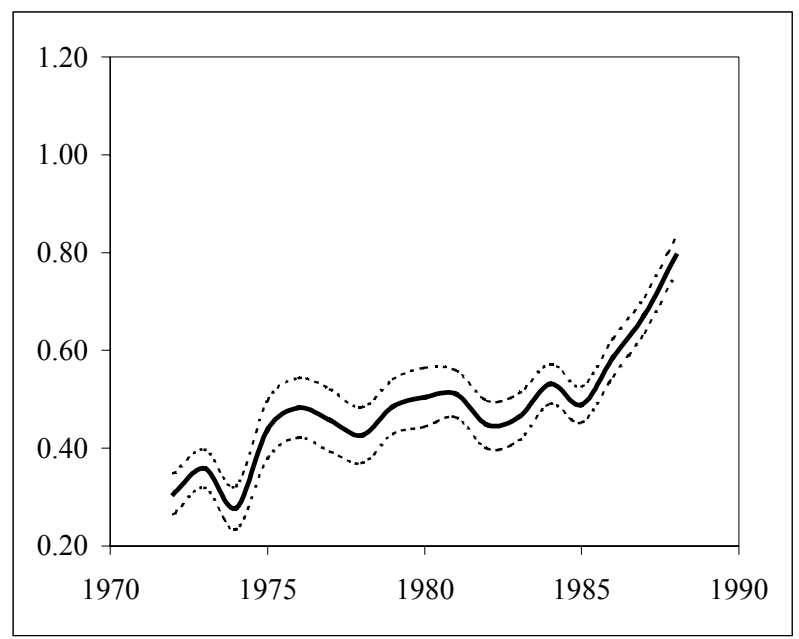

Miscellaneous Manufactures $($ SITC $1=8)$

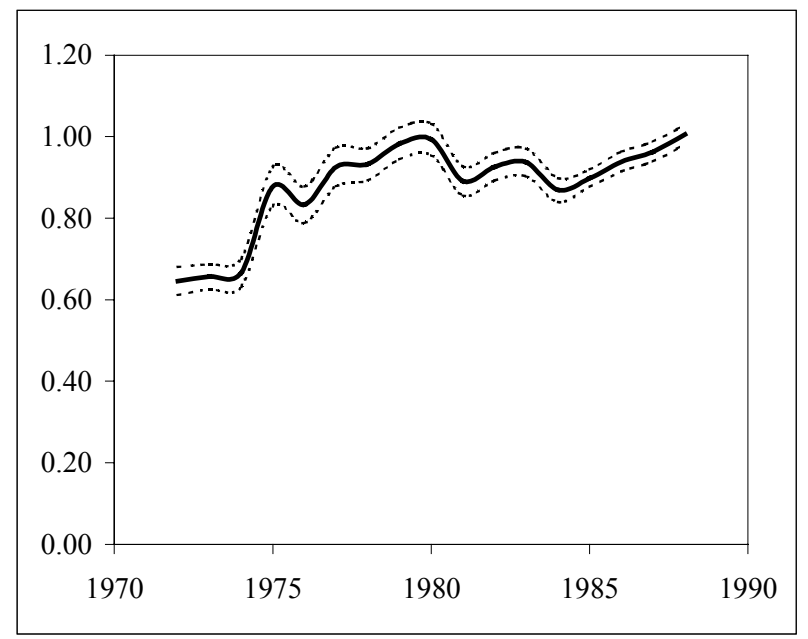

[1] Graphs display industry specific slope and 95\% confidence interval from regression of equation 2 on the constant set of $1972 P M \& R$ goods over time.

[2] Regressions include all products with at least 5 observations which originate in at least one poor, one middle and one rich country in 1972. 
Table 1: Mapping SITC1 Industries to HS10 Products

\begin{tabular}{|l|l|l|r|}
\hline SITC1 Industry & Example of SITC2 Industries & Example of HS Product & $\begin{array}{r}\text { Number of Products in } \\
\text { this Industry in 1994 }\end{array}$ \\
\hline 0 Food & Meat, Dairy Products, Fruit & Sheep, live & 1823 \\
\hline 1 Beverages/Tobacco & Wine, Cigarettes & Carbonated soft drinks & 163 \\
\hline 2 Crude Materials & $\begin{array}{l}\text { Rubber, Cork, Wood, Textile } \\
\text { Fibers }\end{array}$ & $\begin{array}{l}\text { Silkworm cocoons suitable } \\
\text { for reeling }\end{array}$ & 833 \\
\hline 3 Mineral Fuels & $\begin{array}{l}\text { Coal, Coke, Petroleum, Natural } \\
\text { Gas, Electric Current }\end{array}$ & Unleaded gasoline \\
\hline 4 Animal and Vegetable Oils & Lard, Soybean Oil, Linseed Oil & Tallow, edible & 101 \\
\hline 5 Chemicals & $\begin{array}{l}\text { Organic Chemicals, Dyes, } \\
\text { Medicines, Fertilizers, Plastics }\end{array}$ & Chloroform \\
\hline 6 Manufactured Materials & $\begin{array}{l}\text { Leather, Textile Yarn, Paper, } \\
\text { Steel, Cork Products }\end{array}$ & $\begin{array}{l}\text { Diaries and address books, of } \\
\text { paper or paperboard }\end{array}$ & 1930 \\
\hline 7 Machinery & $\begin{array}{l}\text { Power Generating Machinery, } \\
\text { Computers, Autos }\end{array}$ & $\begin{array}{l}\text { Ultrasonic scanning } \\
\text { apparatus }\end{array}$ \\
\hline 8 Miscellaneous Manunfacturing & $\begin{array}{l}\text { Apparel, Footwear, Plumbing, } \\
\text { Scientific Equipment, Cameras }\end{array}$ & $\begin{array}{l}\text { Boys' shorts cotton playsuit } \\
\text { parts, not knit }\end{array}$ & 4219 \\
\hline 9 Not Elsewhere Classified & Special Transactions, Coins, Gold & $\begin{array}{l}\text { Sound recordings for State } \\
\text { Dept use }\end{array}$ & 2898 \\
\hline
\end{tabular}


Table 2: Countries Jumping from Poor to Middle Income Group and Year of Transition

$\begin{array}{cc}\text { Country } & \text { Transition Year } \\ \text { Thailand (THA) } & 1979 \\ \text { Cameroon (CMR) } & 1981 \\ \text { Egypt (EGY) } & 1985 \\ \text { Samoa (WSM) } & 1988 \\ \text { Philippines (PHL) } & 1990 \\ \text { Senegal (SEN) } & 1990 \\ \text { Indonesia (IDN) } & 1991 \\ \text { Sri Lanka (LKA) } & 1993\end{array}$


Table 3: Unit Value versus Origin Country Per Capita GDP: Summary of Product-Level Slope Significance at the 10\% Level, by Year

Percent of

Year Significant Slopes

1972

1973

1974

1975

1976

1977

1978

1979

1980

1981

1982

1983
30

31

29

27

30

29

31

31

30

29

31

31

\section{Number of} PM\&R Products

2,070

1,966

2,048

1,705

1,746

1,717

2,213

2,146

2,360

2,607

2,703

2,865
Percent of

Year Significant Slopes

1984

1985

1986

1987

1988

1989

1990

1991

1992

1993

1994
32

35

35

34

37

35

36

38

44

43

43
Number of PM\&R Products

3,212

4,344

4,033

4,249

4,079

4,962

5,118

5,223

3,167

3,519

3,800

[1] Table reports number of $P M \& R$ products with positive and significant relationship between log unit value and log per capita GDP at the $10 \%$ level of significance

[2] Regressions run on all $P M \& R$ products with at least 5 country observations. 
Table 4: Slopes From Regression of Unit Value on Origin Country Per Capita GDP:

Products Pooled by Year and SITC1 Industry

Coefficient on Log Per Capita GDP, By Industry

\begin{tabular}{|c|c|c|c|c|c|c|c|c|c|}
\hline & $\begin{array}{c}\text { Food } \\
\text { SITC 0 }\end{array}$ & $\begin{array}{c}\text { Beverages } \\
\text { SITC } 1 \\
\end{array}$ & $\begin{array}{c}\text { Materials } \\
\text { SITC } 2 \\
\end{array}$ & $\begin{array}{c}\text { Fuels } \\
\text { SITC } 3\end{array}$ & $\begin{array}{c}\text { Animal Oils } \\
\text { SITC } 4\end{array}$ & $\begin{array}{c}\text { Chemicals } \\
\text { SITC } 5 \\
\end{array}$ & $\begin{array}{c}\text { Manufactured } \\
\text { Materials } \\
\text { SITC 6 } \\
\end{array}$ & $\begin{array}{c}\text { Machinery } \\
\text { SITC } 7\end{array}$ & $\begin{array}{c}\text { Misc } \\
\text { Manufactures } \\
\text { SITC 8 } \\
\end{array}$ \\
\hline 1972 & 0.20 & 0.11 & 0.21 & 0.16 & 0.06 & 0.32 & 0.31 & 0.90 & 0.64 \\
\hline 1973 & 0.22 & -0.07 & 0.18 & 0.14 & 0.11 & 0.33 & 0.37 & 1.02 & 0.66 \\
\hline 1974 & 0.20 & 0.04 & 0.24 & 0.23 & 0.14 & 0.10 & 0.33 & 0.97 & 0.66 \\
\hline 1975 & 0.25 & -0.09 & 0.31 & 0.11 & -0.16 & 0.38 & 0.44 & 1.21 & 0.86 \\
\hline 1976 & 0.23 & -0.03 & 0.28 & 0.18 & 0.43 & 0.36 & 0.49 & 1.05 & 0.80 \\
\hline 1977 & 0.17 & -0.05 & 0.29 & 0.26 & 0.09 & 0.39 & 0.49 & 0.73 & 0.87 \\
\hline 1978 & 0.26 & 0.05 & 0.32 & 0.46 & 0.04 & 0.53 & 0.47 & 1.43 & 0.91 \\
\hline 1979 & 0.29 & 0.01 & 0.38 & 0.36 & 0.04 & 0.53 & 0.56 & 1.08 & 0.96 \\
\hline 1980 & 0.27 & 0.07 & 0.25 & 0.26 & 0.39 & 0.55 & 0.56 & 1.08 & 0.95 \\
\hline 1981 & 0.25 & -0.04 & 0.23 & 0.12 & -0.36 & 0.41 & 0.52 & 1.07 & 0.88 \\
\hline 1982 & 0.28 & -0.09 & 0.23 & 0.29 & 0.18 & 0.51 & 0.48 & 1.05 & 0.90 \\
\hline 1983 & 0.35 & 0.02 & 0.21 & 0.22 & -0.03 & 0.50 & 0.48 & 0.88 & 0.92 \\
\hline 1984 & 0.25 & -0.01 & 0.23 & 0.13 & 0.24 & 0.41 & 0.53 & 0.87 & 0.86 \\
\hline 1985 & 0.21 & -0.01 & 0.28 & 0.22 & 0.10 & 0.34 & 0.49 & 0.89 & 0.88 \\
\hline 1986 & 0.30 & 0.02 & 0.38 & 0.21 & -0.07 & 0.39 & 0.57 & 0.91 & 0.93 \\
\hline 1987 & 0.33 & 0.12 & 0.28 & 0.23 & 0.46 & 0.51 & 0.67 & 0.94 & 0.96 \\
\hline 1988 & 0.40 & 0.01 & 0.27 & 0.17 & 0.13 & 0.47 & 0.78 & 0.97 & 0.99 \\
\hline 1989 & 0.36 & -0.05 & 0.43 & 0.34 & 0.33 & 0.56 & 0.81 & 1.25 & 1.07 \\
\hline 1990 & 0.41 & 0.01 & 0.52 & 0.25 & 0.20 & 0.68 & 0.88 & 1.48 & 1.12 \\
\hline 1991 & 0.43 & 0.16 & 0.46 & 0.42 & 0.17 & 0.66 & 0.89 & 1.57 & 1.19 \\
\hline 1992 & 0.47 & 0.13 & 0.49 & 0.31 & 0.35 & 0.63 & 0.93 & 1.40 & 1.10 \\
\hline 1993 & 0.45 & 0.15 & 0.46 & 0.09 & 0.67 & 0.70 & 0.90 & 1.28 & 1.13 \\
\hline 1994 & 0.43 & 0.15 & 0.48 & 0.16 & 0.27 & 0.79 & 0.88 & 1.31 & 1.07 \\
\hline
\end{tabular}

